\title{
Effects of Age and Sex on Weight-Loss Dynamics in Obese Patients Undergoing Very Low Calorie Treatment
}

\author{
Edward Jo ${ }^{1,2}$, Angelina Cain ${ }^{4}$, Carla M. Prado ${ }^{2,3}$, Ann F. Brown ${ }^{2,5}$, Michael J. Ormsbee ${ }^{2}$, Dawn \\ Smith $^{4}$, Katie Snyder ${ }^{4}$, and Jeong-Su Kim ${ }^{2}$ \\ ${ }^{1}$ Human Performance Research Laboratory, Department of Kinesiology and Health Promotion, \\ California State Polytechnic University Pomona \\ ${ }^{2}$ Department of Nutrition, Food, and Exercise Sciences, Institute of Sports Sciences \& Medicine, \\ Florida State University \\ ${ }^{3}$ Department of Agricultural, Food, and Nutritional Science, University of Alberta, Canada \\ ${ }^{4}$ Tallahassee Memorial Hospital \\ ${ }^{5}$ Department of Movement Sciences, University of Idaho
}

\begin{abstract}
Background and Significance: Although known to effectively provoke large scaled weight-loss, less is known regarding age- and sex-related influences on treatment outcomes of bariatric patients treated with a very-low calorie diet (VLCD) program. Purpose: This study retrospectively examined body composition and metabolic changes induced by a 12-wk proprietary VLCD treatment in obese patients while assessing age and sex differences. Methods: Male $(n=16)$ and female $(n=16)$ patients underwent 12 weeks of VLCD under standard medical care. Results: Older patients exhibited a greater relative loss of FFM compared to younger patients $(\mathrm{p}=0.004)$. Older patients also lost a greater proportion of total weight-loss as FFM ( $\mathrm{p}=0.003)$ and lower proportion as FM ( $\mathrm{p}=0.003$ ) compared to the young group. This age-specific difference in weight-loss composition was driven by the older males. Conclusion: The results demonstrate the need for special clinical considerations for VLCD treated patients, such as older adults and perhaps older males specifically, who demonstrate a reduced quality of weight-loss compared to their younger counterpart.
\end{abstract}

(C) 2017 Californian Journal of Health Promotion. All rights reserved. Keywords: weight-loss, weight-recidivism, body composition, obesity

\section{Introduction}

Epidemiological findings from the National Health and Nutrition Examination Survey (NHANES 2011-2014) reported that just over $36 \%$ of U.S. adults are currently classified as obese, while $16 \%$ represent incidences of severe cases (Ogden, Carroll, Fryar, \& Flegal, 2015). Obesity reflects a prevalence rate far exceeding the threshold of $15 \%$ set by the World Health Organization (WHO) for epidemics needing intervention (Flegal, Carroll, Kit, \& Ogden, 2012). In fact, a recent comprehensive analysis indicated that in 2015, high body mass index (BMI) contributed to 4.0 million deaths globally (7.1\% of deaths) which represents a $28 \%$ increase from 1990 (Collaborators, 2017). A high BMI also accounted for 28.6 million years lived with disability $(3.6 \%$ of all cause of disability) (Collaborators, 2017). Hence, national health initiatives have prompted the urgency for effective clinical treatments to reconcile the global spread of obesity and subdue the heightened socioeconomic burdens directly attributable to this epidemic (Ogden et al., 2015). Despite the methodological advancement in treatment options, such as surgical- or pharmacological-based approaches, medically supervised weight-loss programs incorporating hypocaloric dietary modifications have remained an ongoing and widely prescribed therapy for obesity (Tsai \& Wadden, 2005). Amongst hypocaloric approaches, proprietary very low calorie diet (VLCD) programs $\left(\sim 800 \mathrm{kcal} /\right.$ day), e.g. Optifast ${ }^{\circledR}$ (Nestlé HealthCare Nutrition), have been medically 
prescribed as a purportedly viable option for high-risk patients whose body mass index (BMI) exceeds $30 \mathrm{~kg} / \mathrm{m}^{2}$, or exhibit critical mortality risk, or have failed to respond favorably to conventional and unmonitored weight-loss programs.

VLCD prescriptions, which are based mostly on liquid meal replacement formulas, have been consistent with outcomes of revitalized health with significant body weight (BW) reductions ranging between $15-27 \%$ in obese subjects (Donnelly et al., 1993; Tsai \& Wadden, 2005; Wadden \& Frey, 1997; Walsh \& Flynn, 1995). This loss in total body mass, however, cannot be solely accounted for by reduced adiposity, but also significant deficits in FFM, especially for the highly metabolically active skeletal muscle (Bryner et al., 1999; Chaston, Dixon, \& O'Brien, 2007; Donnelly, Jakicic, \& Gunderson, 1991; Donnelly et al., 1993; Eston et al., 1992; McIver, Wycherley, \& Clifton, 2012). A meta-analysis revealed a positive correlation between the loss of FFM and degree of energy restriction $\left(r^{2}=\right.$ $0.31, \mathrm{p}=0.006$ ), supporting the contention that a hallmark manifestation of VLCD treatment is a greater loss of FFM compared to less restrictive approaches (e.g. low calorie diet, LCD). In fact, a recent study showed that VLCD treated subjects lost a greater proportion of their weight as FFM compared to LCD treated subjects (Vink, Roumans, Arkenbosch, Mariman, \& van Baak, 2016). Mitigating this reduction in FFM during intentional rapid weight-loss, as induced by VLCD, is of particular significance in older adults, in order to avoid a potential exacerbation of age-related loss of lean mass (sarcopenia), which may lead to profound debility and impaired quality of life. Therefore, the purpose of this retrospective study was to determine the effects of age and sex on weight-loss dynamics in VLCD-treated obese patients.

\section{Methods}

\section{Study Design and Participants}

This study was a single-center retrospective analysis on 32 patients (age $=58 \pm 2 \mathrm{yrs}$ ) of $\mathrm{TMH}$ Bariatric Center who completed a 12-week medical weight-management program incorporating a proprietary VLCD (Optifast ${ }^{\circledR}$;
Nestlé HealthCare Nutrition; Florham Park, New Jersey, USA) between the years 2011 and 2013. Body composition, anthropometric, and metabolic panel data acquired during the 12week treatment period were analyzed retrospectively from medical chart reviews of male $(n=16)$ and female $(n=16)$ patients. Timedependent changes in dependent variables were compared among gender and age cohorts. Age groups were determined by patient cohorts above and below the median age of 57 years, i.e. Young $=<57$ yrs. $(\mathrm{n}=16)$ and $\mathrm{Old}=\geq 57 \mathrm{yrs}$. $(n=16)$. All baseline descriptive measures are indicated in Table 1 for the total, sex, and age cohorts. Patients included for analysis met the following criteria: 1) full completion of the 12-

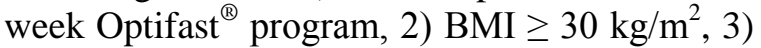
sedentary behavior (based on self-reported physical activity level), and 4) at least 18 years of age. All data sets were numerically coded with no accessible link to patient information. This investigation was approved by the Institutional Review Boards of Florida State University and TMH.

\section{Measure and Procedures}

Dietary Treatment Program. The medical weight-management program of focus was administered at the TMH Bariatric Center and prescribed by a board certified bariatric physician. The program incorporated a 12-week rapid weight-loss treatment period comprised of full meal-replacement administered through liquid- and solid-based formulas, i.e. Optifast ${ }^{\circledR}$. No other foods outside of the Optifast ${ }^{\circledR}$ products were consumed during the treatment period. A standard Optifast ${ }^{\circledR}$ treatment is implemented through a variety of products comprised of a powder mix, ready-to-drink blend, instant soup, and bars, all of which contain equivalent macronutrient (i.e. $35 \%$ protein, $50 \%$ carbohydrate, and $15 \%$ fat) and micronutrient composition per product, equating to 160 kcals/product. Participants were prescribed 5 products a day yielding a total of $800 \mathrm{kcals}, 70 \mathrm{~g}$ of protein, $100 \mathrm{~g}$ of carbohydrates, $15 \mathrm{~g}$ of fat, and $100 \%$ of the Daily Value for 24 vitamins and minerals. Participants were medically supervised and required to visit the $\mathrm{TMH}$ Bariatric Center each week on a designated time and day. During each visit, participants 
underwent anthropometric assessments and attended a group education class mediated by a registered dietician. The bariatric physician monitored the participant's progress and medical condition regularly throughout the treatment period.

Table 1

Mean Values for Descriptive Variables for Total, Sex, and Age Cohorts

\begin{tabular}{lccccc}
\hline & $\begin{array}{c}\text { Total } \\
(\mathrm{N}=32)\end{array}$ & $\begin{array}{c}\text { Male } \\
(\mathrm{n}=16)\end{array}$ & $\begin{array}{c}\text { Female } \\
(\mathrm{n}=16)\end{array}$ & $\begin{array}{c}\text { Young } \\
(\mathrm{n}=16)\end{array}$ & $\begin{array}{c}\text { Old } \\
(\mathrm{n}=16)\end{array}$ \\
\hline Age & 58.1 & 58.9 & 57.6 & 51.4 & 65.1 \\
$(\mathrm{yrs})$ & $(1.5)$ & $(2.3)$ & $(2.1)$ & $(1.1)^{\wedge}$ & $(1.5)^{\wedge}$ \\
$\mathrm{BW}$ & 131.2 & 143.2 & 119.1 & 137.4 & 124.9 \\
$(\mathrm{~kg})$ & $(4.2)$ & $(4.2)^{*}$ & $(6.1)^{*}$ & $(5.2)$ & $(6.5)$ \\
Height & 169.0 & 177.2 & 160.8 & 171.9 & 166.1 \\
$(\mathrm{~cm})$ & $(1.9)$ & $(1.4) \dagger$ & $(2.1) \dagger$ & $(3.0)$ & $(2.2)$ \\
$\mathrm{FM}$ & 62.1 & 62.2 & 62.0 & 67.8 & 56.4 \\
$(\mathrm{~kg})$ & $(2.7)$ & $(3.4)$ & $(4.3)$ & $(3.4) \gamma$ & $(3.7) \gamma$ \\
FFM & 69.1 & 81.0 & 57.1 & 69.6 & 68.5 \\
$(\mathrm{~kg})$ & $(2.9)$ & $(3.2) \dagger$ & $(2.2) \dagger$ & $(3.5)$ & $(4.6)$ \\
$\mathrm{BMI}$ & 45.8 & 45.6 & 46.1 & 46.6 & 45.1 \\
$\left(\mathrm{~kg} / \mathrm{m}^{2}\right.$ & $(1.3)$ & $(1.3)$ & $(2.3)$ & $(1.7)$ & $(2.0)$ \\
) & & & & 138.3 & 137.0 \\
WC & 137.6 & 144.2 & 131.0 & 13.3 \\
$(\mathrm{~cm})$ & $(2.6)$ & $(2.7)^{*}$ & $(3.8)^{*}$ & $(3.1)$ & $(4.2)$ \\
\hline
\end{tabular}

$\mathrm{BW}=$ body weight, $\mathrm{FM}=$ fat mass, $\mathrm{FFM}=$ fat free mass, $\mathrm{BF} \%=$ body fat percentage, $\mathrm{FFM} \%=$ fat free mass percentage, $\mathrm{BMI}=$ body mass index, $\mathrm{WC}=$ waist circumference. Age cohorts split above and below median age $(57 \mathrm{yrs})$, i.e. Young $=$ age $<57$; Old $=$ age $\geq 57$. Values reported as mean (SE).

different between sexes $(* p<0.009),(\dagger p<0.0001)$

different between age-groups $\left(\wedge^{\wedge}<0.0001\right),(\gamma p=0.32)$

\section{Anthropometry and Body Composition.} Anthropometric parameters and body composition (two-compartment model) were measured at the TMH Bariatric Center using an FDA-approved medical body composition analyzer (Tanita TBF-310; Arlington Heights, Illinois, USA) that is equipped with a BW scale and bioelectrical impedance analysis (BIA) capabilities. The analyzer provided computed measurements for BW, BMI, body fat percentage $(\mathrm{BF} \%)$, fat mass $(\mathrm{FM})$, and lean mass as fat free mass (FFM) (i.e. FFM = BW - FM); the FFM compartment includes lean soft tissues plus bone mineral content. Percentage of FFM of total BW (FFM\%) was extrapolated from BIA data. Waist circumference (WC) was measured through a previously described protocol (Berk et al., 2012). BW and BMI were recorded each week during the 12-week treatment period. Body composition and anthropometric variables, i.e. FM, FFM, BF\%, FFM\%, and WC, were measured once pre- and post-treatment. The body composition analyzer demonstrated good reliability with a test re-test coefficient of variation of $1.6 \%$.

Metabolic Panel. Lipid panels included values for total cholesterol, triacylglycerol (TAG), high-density lipoprotein (HDL), low-density lipoprotein (LDL) and very low-density lipoprotein (VLDL). Other metabolic tests included fasting blood glucose levels as well as hemoglobin A1c (HbA1c) values. All measures were obtained in the 8-hour fasted state. Systemic metabolic profiles were measured preand post-treatment.

\section{Statistical Analyses}

All data are presented as mean \pm standard error (SE). All descriptive variables were analyzed using a dependent student t-test for baseline comparisons between sexes and between agegroups. Pre- and post-treatment measurements for body composition, anthropometric, and metabolic biomarkers were analyzed using a 2 (sex) x 2 (age) x 2 (time) repeated measures ANOVA. Relative change from pre- to posttreatment for all dependent variables were calculated and analyzed by a 2 (sex) x 2 (age) multifactorial ANOVA. In the event of a significant main effect or interaction, a Tukey post hoc test was used for pairwise comparisons. All statistical analyses were performed using Statistical Package for Social Sciences (SPSS) with significance set at $\mathrm{p}<0.05$.

\section{Body Composition}

\section{Results}

There was a significant change from pre- to post-treatment for all body composition and anthropometric variables when examining the sample in aggregate as well as in individual sex and age cohorts (Tables 2-4). 
Jo, E., Cain, A., Prado, C.M., Brown, A.F., Ormsbee, M.J., Smith, D., Snyder, K., Kim, J-S. / Californian Journal of Health Promotion 2017, Volume 15, Issue 3, 25-36.

Table 2

Pre- and Post-treatment Means for Anthropometric and Body Composition Measures for Total Sample

\begin{tabular}{|c|c|c|c|}
\hline & \multicolumn{3}{|c|}{ Total $(\mathrm{N}=32)$} \\
\hline & Pre & Post & $\Delta(\%)$ \\
\hline $\begin{array}{l}\mathrm{BW} \\
(\mathrm{kg})\end{array}$ & $\begin{array}{r}131.2 \\
(4.2)\end{array}$ & $109.0(4.0)$ & $-17.2(1.0)^{*}$ \\
\hline $\begin{array}{l}\text { FM } \\
(\mathrm{kg})\end{array}$ & $62.1(2.7)$ & $45.5(2.9)$ & $-27.8(2.2)^{*}$ \\
\hline $\begin{array}{l}\text { FFM } \\
(\mathrm{kg})\end{array}$ & $69.1(2.9)$ & $63.5(2.6)$ & $-8.0(0.9)^{*}$ \\
\hline $\begin{array}{l}\text { BMI } \\
\left(\mathrm{kg} / \mathrm{m}^{2}\right)\end{array}$ & $45.9(1.3)$ & $38.1(1.3)$ & $-17.2(1.0)^{*}$ \\
\hline $\begin{array}{l}\text { WC } \\
(\mathrm{cm})\end{array}$ & $137.6(2.6)$ & $119.1(2.9)$ & $-13.6(1.0)^{*}$ \\
\hline $\begin{array}{l}\mathrm{BW}=\mathrm{bc} \\
\text { mass, } \\
\text { circumfe } \\
\text { post-inte } \\
* \quad \text { Sign } \\
(\mathrm{p}<0.000\end{array}$ & $\begin{array}{l}\text { y weight, } \\
\text { MI= body } \\
\text { nce. } \Delta=\text { me } \\
\text { ention. Val } \\
\text { icant pre- } \\
\end{array}$ & $\begin{array}{l}\mathrm{I}=\text { fat mass } \\
\text { mass index, } \\
\text { relative cha } \\
\text { s reported as } \\
\text { to post-trea }\end{array}$ & $\begin{array}{l}\mathrm{M}=\text { fat free } \\
\mathrm{WC}=\text { waist } \\
\text { from pre- to } \\
\text { an }(\mathrm{SE}) \text {. } \\
\text { ent change }\end{array}$ \\
\hline
\end{tabular}

Table 3

Sex-specific Pre-and Post-intervention Means and Relative Change for Anthropometric and Body Composition Measures

\begin{tabular}{lrrrrrr}
\hline & \multicolumn{3}{c}{ MALE (n= 16) } & \multicolumn{2}{c}{ FEMALE (n=16) } \\
\hline & Pre & Post & $\Delta(\%)$ & Pre & Post & $\begin{array}{r}\Delta \\
(\%)\end{array}$ \\
\hline BW & 143.2 & 117. & -17.7 & 119.1 & 100.3 & -16.6 \\
$(\mathrm{~kg})$ & $(4.2)$ & 7 & $(1.3)^{*}$ & $(6.1)$ & $(6.5)$ & $\begin{array}{r}* \\
*\end{array}$ \\
& & $(3.9)$ & & & & -24.1 \\
FM & 62.2 & 42.7 & -31.4 & 62.0 & 48.3 & $(3.0)$ \\
$(\mathrm{kg})$ & $(3.4)$ & $(3.2)$ & $(3.0)^{*}$ & $(4.3)$ & $(4.8)$ & $*$ \\
& & & & & & -9.0 \\
FFM & 81.0 & 74.9 & -7.0 & 57.1 & 52.0 & $(0.8)$ \\
$(\mathrm{kg})$ & $(3.2)$ & $(2.4)$ & $(1.5)^{*}$ & $(2.2)$ & $(2.1)$ & $*$ \\
& & & & & & -16.6 \\
BMI & 45.6 & 37.5 & -17.7 & 46.1 & 38.8 & $(1.5)$ \\
$\left(\mathrm{kg} / \mathrm{m}^{2}\right)$ & $(1.3)$ & $(1.2)$ & $(1.3)^{*}$ & $(2.3)$ & $(2.4)$ & $*$ \\
& & 126. & & & & -14.6 \\
WC & 144.2 & 0 & -12.6 & 131.0 & 112.2 & $(1.5)$ \\
$(\mathrm{cm})$ & $(2.7)$ & $(2.9)$ & $(2.8)^{*}$ & $(3.8)$ & $(4.4)$ & $*$ \\
\hline BW & & & & & & \\
& & & & &
\end{tabular}

$\mathrm{BW}=$ body weight, $\mathrm{FM}=$ fat mass, $\mathrm{FFM}=$ fat free mass, $\mathrm{BMI}=$ body mass index, $\mathrm{WC}=$ waist circumference. $\Delta=$ mean relative change from pre- to postintervention. Values reported as mean (SE).

* Significant pre- to post-treatment change $(\mathrm{p}<0.001)$
Table 4

Age-specific Pre-and Post-intervention Means for Body Composition and Anthropometric Measures

\begin{tabular}{lrrrrrr} 
& \multicolumn{3}{c}{ Young $(\mathrm{n}=16)$} & \multicolumn{3}{c}{ Old $(\mathrm{n}=16)$} \\
\hline & Pre & Post & $\Delta(\%)$ & Pre & Post & $\Delta(\%)$ \\
\hline BW & 137.4 & 114.2 & -17.3 & 124.9 & 103.8 & -17.1 \\
$(\mathrm{~kg})$ & $(5.2)$ & $(5.5)$ & $(1.5)^{*}$ & $(6.5)$ & $(5.8)$ & $(1.5)^{*}$ \\
FM & 67.8 & 48.3 & -30.2 & 56.4 & 42.7 & -25.4 \\
$(\mathrm{~kg})$ & $(3.4)$ & $(4.4)$ & $(3.5)^{*}$ & $(3.7)$ & $(3.7)^{*}$ & $(2.6)^{*}$ \\
FFM & 69.6 & 65.8 & -5.7 & 68.5 & 61.1 & -10.3 \\
$(\mathrm{~kg})$ & $(3.5)$ & $(3.6)$ & $(1.0)^{* \wedge}$ & $(4.6)$ & $(3.7)^{*}$ & $(1.3)^{* \wedge}$ \\
$\mathrm{BMI}$ & 46.6 & 38.7 & -17.3 & 45.1 & 37.6 & -17.1 \\
$\left(\mathrm{~kg} / \mathrm{m}^{2}\right)$ & $(1.7)$ & $(1.8)$ & $(1.5)^{*}$ & $(2.0)$ & $(2.0)^{*}$ & $(1.5)^{*}$ \\
$\mathrm{WC}$ & 138.3 & 118.1 & -14.7 & 137.0 & 120.2 & -12.5 \\
$(\mathrm{~cm})$ & $(3.1)$ & $(3.7)$ & $(1.4)^{*}$ & $(4.2)$ & $(4.5)^{*}$ & $(1.4)^{*}$ \\
\hline $\mathrm{BW}$ & & & & &
\end{tabular}

$\mathrm{BW}=$ body weight, $\mathrm{FM}=$ fat mass, $\mathrm{FFM}=$ fat free mass, $\mathrm{BMI}=$ body mass index, $\mathrm{WC}=$ waist circumference. $\Delta=$ mean relative change from pre- to post-intervention. Values reported as mean $(\mathrm{SE})$. Young= age $<57$; Old $=$ age $\geq 57$.

* Significant pre- to post-treatment change $(\mathrm{p}<0.05)$

$\wedge$ Significantly different between age-groups $(p=0.004)$

There were no significant differences between sexes for the pre- to post-treatment reductions in BW ( $\mathrm{p}=0.61), F M(\mathrm{p}=0.10)$, FFM $(\mathrm{p}=0.17)$, BMI $(\mathrm{p}=0.61)$, or $\mathrm{WC}(\mathrm{p}=0.31)$ (Table 3$)$. The relative pre- to post-treatment change in $\mathrm{BW}(\mathrm{p}=0.94), \mathrm{FM}$ $(\mathrm{p}=0.27)$, WC $(\mathrm{p}=0.28)$, or BMI $(\mathrm{p}=0.91)$ was equivalent between age-groups (Table 4). However, the old-group demonstrated a greater relative loss in FFM than the young-group $(\mathrm{p}=0.004)$.

There was a sex by age interaction for the relative pre- to post-treatment loss of (FFM ( $\mathrm{p}=0.013)$, while no interaction was detected for all other measures (Table 5). Post hoc analysis revealed that older males relatively lost more FFM than younger males $(\mathrm{p}=0.0003)$. There were no differences in relative FFM-loss between female age cohorts $(\mathrm{p}=0.72)$. Further, younger females lost more FFM, relatively, than younger males $(\mathrm{p}=0.008)$ while, in the older cohort, there were no differences between sexes for the relative loss of FFM ( $\mathrm{p}=0.39)$. 
Jo, E., Cain, A., Prado, C.M., Brown, A.F., Ormsbee, M.J., Smith, D., Snyder, K., Kim, J-S. / Californian Journal of Health Promotion 2017, Volume 15, Issue 3, 25-36.

Table 5

Sex by Age-group Main Effect and Interaction for Body Composition and Anthropometric Measures

\begin{tabular}{|c|c|c|c|c|c|c|c|c|c|c|c|c|}
\hline & \multicolumn{6}{|c|}{ Young $(n=16)$} & \multicolumn{6}{|c|}{ Old $(n=16)$} \\
\hline & \multicolumn{3}{|c|}{ Male $(n=8)$} & \multicolumn{2}{|c|}{ Female $(n=8)$} & \multirow[b]{2}{*}{$\Delta(\%)$} & \multicolumn{2}{|c|}{ Male $(n=8)$} & \multirow[b]{2}{*}{$\Delta(\%)$} & \multicolumn{2}{|c|}{ Female $(n=8)$} & \multirow[b]{2}{*}{$\Delta(\%)$} \\
\hline & Pre & Post & $\Delta(\%)$ & Pre & Post & & Pre & Post & & Pre & Post & \\
\hline $\begin{array}{l}\text { BW } \\
(\mathrm{kg})\end{array}$ & $\begin{array}{l}146.6 \\
(3.9)\end{array}$ & $\begin{array}{l}120.1 \\
(5.3)\end{array}$ & $\begin{array}{l}-18.2 * \\
(2.1)\end{array}$ & $\begin{array}{l}128.2 \\
(8.0)\end{array}$ & $\begin{array}{l}108.3 \\
(8.8)\end{array}$ & $\begin{array}{l}- \\
16.3 * \\
(1.8)\end{array}$ & $\begin{array}{l}139.8 \\
(7.1)\end{array}$ & $\begin{array}{l}115.3 \\
(5.2)\end{array}$ & $\begin{array}{l}-17.2 * \\
(1.6)\end{array}$ & $\begin{array}{l}110.0 \\
(7.4)\end{array}$ & $\begin{array}{l}92.2 \\
(8.1)\end{array}$ & $\begin{array}{l}- \\
17.0^{*} \\
(2.3)\end{array}$ \\
\hline $\begin{array}{l}\text { FM } \\
(\mathrm{kg})\end{array}$ & $\begin{array}{l}66.8 \\
(4.2)\end{array}$ & $\begin{array}{l}42.5 \\
(4.8)\end{array}$ & $\begin{array}{l}-37.0 * \\
(4.6)\end{array}$ & $\begin{array}{l}68.8 \\
(5.1)\end{array}$ & $\begin{array}{l}54.2 \\
(6.3)\end{array}$ & $\begin{array}{l}- \\
23.4 * \\
(3.9)\end{array}$ & $\begin{array}{l}57.6 \\
(4.4)\end{array}$ & $\begin{array}{l}42.9 \\
(3.8)\end{array}$ & $\begin{array}{l}-25.9 * \\
(2.7)\end{array}$ & $\begin{array}{l}55.2 \\
(5.7)\end{array}$ & $\begin{array}{l}42.5 \\
(6.0)\end{array}$ & $\begin{array}{l}- \\
24.8 * \\
(4.5)\end{array}$ \\
\hline $\begin{array}{l}\text { FFM } \\
(\mathrm{kg})\end{array}$ & $\begin{array}{l}79.8 \\
(3.0)\end{array}$ & $\begin{array}{l}77.6 \\
(2.6)\end{array}$ & $\begin{array}{l}- \\
2.6 * \wedge \dagger \\
(0.8)\end{array}$ & $\begin{array}{l}59.4 \\
(3.4)\end{array}$ & $\begin{array}{l}54.1 \\
(2.9)\end{array}$ & $\begin{array}{l}- \\
8.7 * \wedge \\
(1.0)\end{array}$ & $\begin{array}{l}82.2 \\
(5.3)\end{array}$ & $\begin{array}{l}72.4 \\
(3.5)\end{array}$ & $\begin{array}{l}- \\
11.3^{* \dagger} \\
(2.1)\end{array}$ & $\begin{array}{l}54.8 \\
(2.3)\end{array}$ & $\begin{array}{l}49.8 \\
(2.6)\end{array}$ & $\begin{array}{l}-9.4 * \\
(1.3)\end{array}$ \\
\hline $\begin{array}{l}\text { BMI } \\
\left(\mathrm{kg} / \mathrm{m}^{2}\right)\end{array}$ & $\begin{array}{l}45.0 \\
(1.2)\end{array}$ & $\begin{array}{l}36.8 \\
(1.4)\end{array}$ & $\begin{array}{l}-18.3 * \\
(2.1)\end{array}$ & $\begin{array}{l}48.2 \\
(2.9)\end{array}$ & $\begin{array}{l}40.6 \\
(2.6)\end{array}$ & $\begin{array}{l}- \\
16.4 * \\
(1.8)\end{array}$ & $\begin{array}{l}46.2 \\
(2.2)\end{array}$ & $\begin{array}{l}38.2 \\
(1.8)\end{array}$ & $\begin{array}{l}-17.2 * \\
(1.6)\end{array}$ & $\begin{array}{l}44.1 \\
(3.2)\end{array}$ & $\begin{array}{l}37.0 \\
(3.4)\end{array}$ & $\begin{array}{l}- \\
16.9^{*} \\
(2.3)\end{array}$ \\
\hline $\begin{array}{l}\text { WC } \\
(\mathrm{cm})\end{array}$ & $\begin{array}{l}143.2 \\
(3.0)\end{array}$ & $\begin{array}{l}122.4 \\
(4.0)\end{array}$ & $\begin{array}{l}-14.5^{*} \\
(2.1)\end{array}$ & $\begin{array}{l}133.4 \\
(4.6)\end{array}$ & $\begin{array}{l}113.8 \\
(5.5)\end{array}$ & $\begin{array}{l}- \\
14.8 * \\
(2.3)\end{array}$ & $\begin{array}{l}145.3 \\
(4.3)\end{array}$ & $\begin{array}{l}129.7 \\
(3.3)\end{array}$ & $\begin{array}{l}-10.6^{*} \\
(0.6)\end{array}$ & $\begin{array}{l}128.7 \\
(5.6)\end{array}$ & $\begin{array}{l}110.6 \\
(6.5)\end{array}$ & $\begin{array}{l}- \\
14.4^{*} \\
(1.9)\end{array}$ \\
\hline
\end{tabular}

$\mathrm{BW}=$ body weight, $\mathrm{FM}=$ fat mass, $\mathrm{FFM}=$ fat free mass, $\mathrm{BMI}=$ body mass index, $\mathrm{WC}=$ waist circumference. $\Delta=$ mean relative change from pre- to post-intervention. Values reported as mean (SE). Young= age $<57$; Old $=$ age $\geq$ 57.

* Significant pre- to post-treatment change $(\mathrm{p}<0.001)$

$\wedge$ Significantly different between young males and young females $(\mathrm{p}=0.008)$

$\uparrow$ Significantly different between young males and old males $(\mathrm{p}=0.0003)$

a.

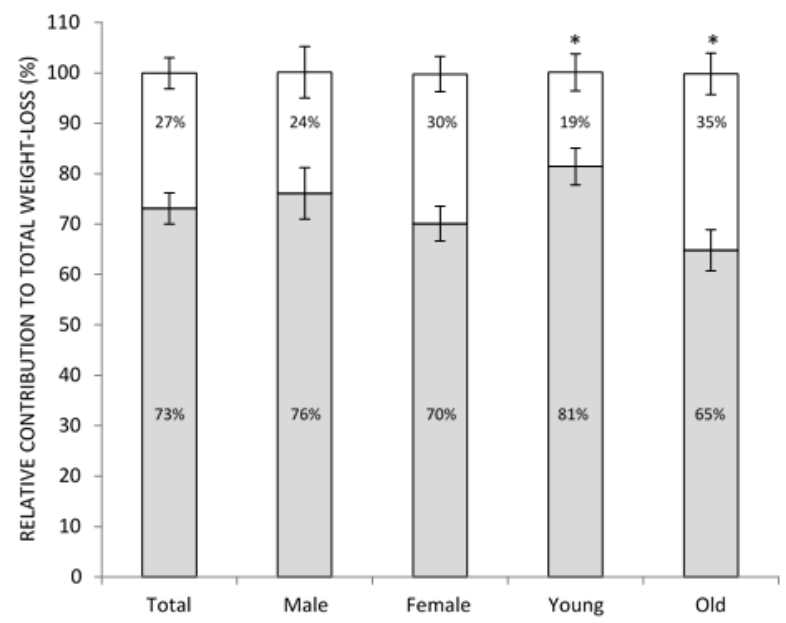

b.

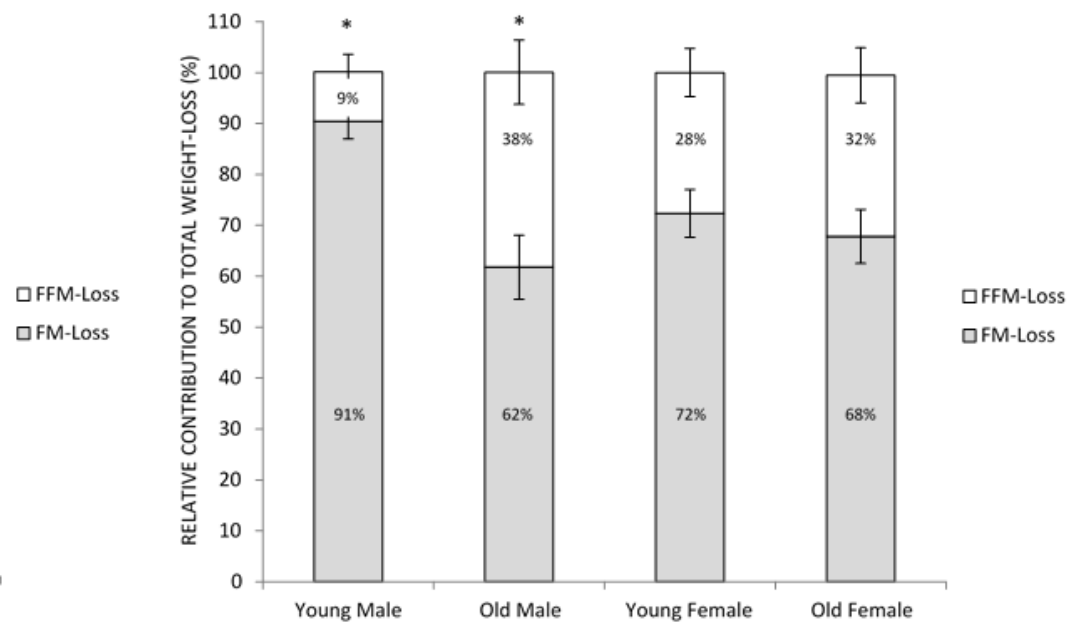

Figure 1. Relative contribution of fat free mass (FFM)- and fat mass (FM)-loss to total weight-loss in a) total sample, sex and age groups and b) age by sex cohorts. Values reported as mean \pm SE. Approximate values for mean relative contributions of FFM- and FM-loss are indicated in respective bars.

$*$ Significantly different between age groups $(\mathrm{p}<0.005)$ 


\section{Contributions of FM- and FFM-Loss to Total Weight-Loss}

The proportion of total weight-loss due to changes in FM and FFM differed across sexes, age-groups (Figure 1a), and sex-age cohorts (Figure 1b). Specifically, the percentage of total weight-loss attributed to reductions in FM was greater for the young-group $(81.4 \pm 3.7 \%$ of total weight-loss) compared to the old-group $(64.8 \pm 4.1 \%$ of total weight-loss $) \quad(p=0.003)$. Also, the percentage of total weight-loss attributed to loss of FFM was lower for the young-group $(18.7 \pm 3.7 \%$ of total weight-loss) compared to the old-group $(35.0 \pm 4.1 \%$ of total weight-loss $) \quad(p=0.003)$. The proportion of weight-loss due to reductions in FM and FFM was not different between sexes. However, a sex by age interaction showed that the proportion of weight-loss due to FM-loss was greater for young-males $(90.5 \pm 3.5 \%$ of total weight-loss) versus old-males $(61.8 \pm 6.3 \%$ of total weightloss $)(\mathrm{p}=0.002)$ (Figure 1b). Also, FFM-loss accounted for a greater proportion of total weight-loss in old-males $(38.3 \pm 6.3 \%$ of total weight-loss) compared to young-males $(9.7 \pm 3.4 \%$ of total weight-loss $) \quad(\mathrm{p}=0.002)$ (Figure 1b).

\section{Blood Metabolic Profile}

There was a significant time effect for $\mathrm{HbA1c}$, fasting glucose, total cholesterol, TAG, and VLDL. From pre- to post-treatment, there was a decrease in HbA1c $(-13.5 \pm 2.7 \%$; $\mathrm{p}=0.0009)$, fasting glucose $(-8.5 \pm 2.7 \% ; \mathrm{p}=0.01)$, total cholesterol $(-8.9 \pm 2.7 \% ; \mathrm{p}=0.004)$, TAG ($21.2 \pm 4.6 \% ; \mathrm{p}=0.001)$, and VLDL $(-20.1 \pm 6.7 \%$; $\mathrm{p}=0.02)$. There was a sex effect for change in $\mathrm{HbA} 1 \mathrm{c}$ as males demonstrated a greater decrease than females pre- to post-treatment $(-18.0 \pm 4.3 \%$ vs. $-7.3 \pm 1.5 \% ; \mathrm{p}=0.04)$. There were no sex or age effects for pre-to-post changes in all other metabolic panel variables.

\section{Discussion}

Overall, the VLCD-based treatment program produced, at least in the short-term, a clinically meaningful weight-loss as evidenced by a significant reduction in adiposity and overall improvement in metabolic profile. The total weight-loss exhibited by the aggregate patient group corroborates outcomes of similar VLCD interventions previously evaluated by Walsh and Flynn (1995) and Wadden et al. (1992). Moreover, a majority of investigations reported that patients who successfully completed a comprehensive VLCD program (that included lifestyle modification) generally lost $15-25 \%$ of initial BW in 3 to 4 months (Anderson, Konz, Frederich, \& Wood, 2001; Astrup \& Rössner, 2000; Mustajoki \& Pekkarinen, 2001; Saris, 2001; Tsai \& Wadden, 2006). The strength of the present findings, however, resides in the differential weight-loss dynamics due to age and sex. A favorable outcome for most weight-loss prescriptions is to maximize the reduction of FM while preserving or improving FFM. Lowered basal metabolic rate, neuromuscular deficits, undue fatigue, poor physical function, and increased risk for musculoskeletal injury have been reported to occur as a result of diminished FFM, especially during advanced aging (Arciero, Goran, \& Poehlman, 1993; Donnelly et al., 2009; Finer, Swan, \& Mitchell, 1986; Nelson, Weinsier, Long, \& Schutz, 1992; Ravussin et al., 1988; Tsai \& Wadden, 2005). Any of these factors taken together with the dramatic loss of FFM would be conducive to impeded fat reduction, weight recidivism, and relapses of prior health complications (Stiegler \& Cunliffe, 2006). Because of the clinical significance of decreased FFM, weight-loss treatments incorporating VLCD or other aggressive modes of dietary modifications remain controversial. The weight-loss composition with a VLCD is approximately $75 \%$ due to FM-loss and $25 \%$ due to FFM-loss (Bray et al., 2012; Weinheimer, Sands, \& Campbell, 2010) which agrees with outcomes of our overall patient cohort. Interestingly, our findings demonstrate the observed weight-loss composition to be significantly affected by age and sex, revealing the limitations and controversies of current VLCD programs that generally fail to consider these evidentially influential factors.

Specific findings of interest include age-related outcomes in weight-loss composition as opposed to simply total BW reduction. Total absolute weight-loss following the 12-week treatment was comparable between age groups $(-17.3 \%$ for 
young and $-17.1 \%$ for old), which may lead to misguided perceptions that VLCD treatments yield equivalent benefits among younger and older patients. However, from a body composition and perhaps weight-loss quality standpoint, our findings suggest that VLCD outcomes are indeed distinct between young and old patients. Our data show that older patients lose about $17 \%$ less FM and 58\% more FFM than their younger counterparts, thereby offsetting any age-related differences in total weight-loss. As presented in Figure 1a, the proportion of weight-loss from FM-loss decreases with age while FFM-loss becomes increasingly contributory. These age-specific effects on FM- and FFM-loss indicate that advancing age may negatively affect the quality of overall weight-loss when induced by VLCD and perhaps other modes of severe dietary restriction. This of course is based on the contention that good weight-loss quality is defined as a significant reduction in FM without compromising FFM. Based on the observed divergence in weight-loss patterns between age groups, the matter of sarcopenia emerges as an important clinical issue especially considering the surmounting population of obese older adults (Goisser et al., 2015).

As a critical manifestation of advanced aging and obesity, previous literature supports the presence of a condition in which obese older adults demonstrate a reduced FFM to BW ratio, poor skeletal muscle quality, impaired physical function, and increased systemic inflammation (Bollheimer et al., 2012; Roubenoff, 2004; Schrager et al., 2007; Thornell, 2011; Zamboni, Mazzali, Fantin, Rossi, \& Di Francesco, 2008). This condition has been collectively termed sarcopenic-obesity, which is fundamentally the coexistence of age-related muscle wasting and excessive adiposity (Zamboni et al., 2008). Consequently, the proper clinical approach to obesity treatment for older adults becomes an immense challenge due to the adverse effects of severe caloric restriction on FFM as evidenced by our current findings. In other words, it may be reasonable to suggest that weight-loss therapies, such as VLCD, exacerbate the sarcopenic progression for older adults. Our results are corroborated by a systematic review of 52 studies that examined age-specific changes in BW and FFM in response to a variable period of energy restriction (Weinheimer et al., 2010). When evaluating weight-loss composition, $50 \%$ of their older study cohorts lost more than $25 \%$ of their BW as FFM. Moreover, intentional weight-loss, even when excess adipose tissue is targeted, also includes accelerated skeletal muscle loss which is inversely associated with functional capacities for autonomous living in older adults (S. L. Miller \& Wolfe, 2008). Collectively, sarcopenic-obesity renders a complex issue for medical practitioners who need to prescribe an appropriate weight-loss treatment that moderates the health risks related to obesity while also preserving muscle to minimize the severity of sarcopenia. Based on our findings, these considerations appear more critical for older male patients who evidently demonstrate greater relative loss in FFM compared to their younger counterparts (Table 5), ultimately manifesting in inferior weight-loss quality (Figure 1b). These responses are intriguing when considering the previous reports indicating the morphological and functional manifestations of sarcopenia to be more severe in men than women (Finer, 2001; Finer et al., 1986; Finkelstein, Fiebelkorn, \& Wang, 2003; Iannuzzi-Sucich, Prestwood, \& Kenny, 2002). Our comprehensive evaluation of age-specific responses confirms the need to restructure the current VLCD-based programs to better optimize weight-loss characteristics for older adults due to the aforesaid issues. Our findings stress the importance for healthcare professionals to thoroughly evaluate the risks and benefits of VLCD prescriptions especially for older adults and tailor treatment programs accordingly. This leads us to the question of how VLCD systems, like Optifast ${ }^{\circledR}$, can be enhanced through practical interventions.

As others have noted, exercise continues to be a key component of successful dietary weight-loss endeavors (Arciero, Baur, Connelly, \& Ormsbee, 2014; Arciero et al., 2006; Bryner et al., 1999; Johannsen et al., 2012; Longland, Oikawa, Mitchell, Devries, \& Phillips, 2016). As discussed by Miller et al. (2013), exercise affects a wide range of physiological, behavioral, and psychosocial variables, which in 
most cases are considered more positive than negative for the weight-loss patient. For instance, Villareal et al. (2011) showed a $21 \%$ improvement in physical performance test scores when energy restriction was combined with formal exercise training, while the absence of exercise resulted in only a $12 \%$ increase. Also, exercise training, mostly aerobic, has been previously scrutinized as a means of enhancing weight-loss composition and/or resting metabolic rate during dietary restriction in obese participants but has shown equivocal outcomes (Bamman et al., 2001; Donnelly, Pronk, Jacobsen, Pronk, \& Jakicic, 1991; Fine et al., 1999; Hammer, Barrier, Roundy, Bradford, \& Fisher, 1989; Hill, Sparling, Shields, \& Heller, 1987; Pavlou, Steffee, Lerman, \& Burrows, 1985). Resistance training, more specifically systematic and periodized resistance training, has been less examined despite its known potency in promoting anabolic adaptations in skeletal muscle. Further, typical VLCD systems and treatment programs fail to integrate sophisticated and structured applications of exercise assumingly due to the limited availability and translation of data to properly guide medical practitioners.

Another area of concern is the relative protein content of VLCD. Previous findings suggest that the custom protein composition of the Optifast ${ }^{\circledR}$ system is rather inadequate especially if combined with a resistance training intervention. For instance, the current study cohort at a mean initial BW of $131 \mathrm{~kg}$ would consume a VLCD providing only $0.5 \mathrm{~g}$ of protein $/ \mathrm{kg}$ bodyweight/day. Thus, VLCD formulations like Optifast with a protein dose of $70 \mathrm{~g} / \mathrm{day}$ would fall below the RDA of $0.8 \mathrm{~g} / \mathrm{kg} /$ day. Metaanalyses suggested that higher-protein consumption of approximately $1.2 \mathrm{~g} / \mathrm{kg} /$ day promotes greater LM maintenance than diets lower in protein $(<0.7 \mathrm{~g} / \mathrm{kg} /$ day $)$ under weightloss circumstances, particularly when combined with resistance training (Krieger, Sitren, Daniels, \& Langkamp-Henken, 2006; Weinheimer et al., 2010). In fact, Pasiakos et al. (2013) showed that consuming 2-3 times above the RDA protein intake lowers the relative contribution of LM-loss to the total weight reduced during energy restrictive periods.
Therefore, the RDA for protein intake, and thereby customary Optifast ${ }^{\circledR}$ protein content, remains insufficient for the preservation of $\mathrm{LM}$, especially for the average $131 \mathrm{~kg}$ patient. Based on mean BW data from the current study, in addition to the aforesaid protein recommendation $(1.2 \mathrm{~g} / \mathrm{kg} / \mathrm{day})$, approximately $150 \mathrm{~g}$ of protein per day would be required for the maintenance of LM during a VLCD intervention. In a recent study by Longland et al. (2016), a higher protein intake of 2.4 $\mathrm{g} / \mathrm{kg} /$ day compared to $1.2 \mathrm{~g} / \mathrm{kg} /$ day yielded superior outcomes for LM as well as FM during an energy deficit combined with resistance training. These findings along with the present provide excellent support for the combined implementation of higher protein intake and resistance training in VLCD or hypocaloric treatment programs for obesity.

The most noteworthy contribution of the current study is that proprietary weight-loss systems can be evaluated and translated in a scientifically apt manner. We expect our report to enable both the patient and practitioner a better opportunity to assess the risk and efficacy of proprietary VLCD programs with information beyond what is commercially advertised. We also anticipate our current investigation to act as a model for the medical nutrition industry to systematically evaluate dietary weight-loss products through scientifically sound research with complete transparency with their findings. As in the pharmaceutical industry, product evaluations and reporting should be mandated within the nutrition industry to prevent falsified or misleading advertising, which unfortunately has become quite pervasive.

Overall, our findings demonstrate the considerable need for treatment optimization as it pertains to the post-VLCD management of BW and adiposity. Given the supported health benefits of VLCD-induced weight-loss for the severely obese, it becomes an imperative goal to generate post-treatment conditions that would minimize the chance for a patient to relapse into unhealthy weight-gain. Patients generally regain 40 to $50 \%$ of BW lost approximately one to two years post-VLCD, especially in the absence of follow-up care (Tsai \& Wadden, 2006; Wadden, 
Foster, Letizia, \& Stunkard, 1992; Wadden \& Frey, 1997). Based on our current assessment of the 12-week Optifast ${ }^{\circledR}$ program, patients experience a reduction in FFM, which in certain cohorts, i.e. old males, is presented more severely than others. Because the preservation of FFM, metabolic rate, and physical function plays a critical role in the long-term maintenance of healthy weight status, practical interventions (i.e. resistance training, protein modifications) with large potential to address these factors should be integrated into VLCD-based treatment plans. Overall, our findings from this investigation support the need for the clinical integration of structured exercise training and protein modifications with the purpose of 1) optimizing weight-loss composition as well as metabolic and functional outcomes; and 2) promoting lifestyle modifications conducive to healthy weight status and long-term management.

\section{References}

Anderson, J. W., Konz, E. C., Frederich, R. C., \& Wood, C. L. (2001). Long-term weight-loss maintenance: A meta-analysis of us studies. American Journal of Clinical Nutrition, 74(5), 579584.

Arciero, P. J., Baur, D., Connelly, S., \& Ormsbee, M. J. (2014). Timed-daily ingestion of whey protein and exercise training reduces visceral adipose tissue mass and improves insulin resistance: The prise study. Journal of Applied Physiology (1985), 117(1), 1-10. doi:10.1152/japplphysiol.00152.2014

Arciero, P. J., Gentile, C. L., Martin-Pressman, R., Ormsbee, M. J., Everett, M., Zwicky, L., \& Steele, C. A. (2006). Increased dietary protein and combined high intensity aerobic and resistance exercise improves body fat distribution and cardiovascular risk factors. International Journal of Sport Nutrition and Exercise Metabolism, 16(4), 373-392.

Arciero, P. J., Goran, M. I., \& Poehlman, E. T. (1993). Resting metabolic rate is lower in women than in men. Journal of Applied Physiology, 75(6), 2514-2520.

Astrup, A., \& Rössner, S. (2000). Lessons from obesity management programmes: Greater initial weight loss improves long-term maintenance. Obesity Review, 1(1), 17-19.

Bamman, M. M., Shipp, J. R., Jiang, J., Gower, B. A., Hunter, G. R., Goodman, A., . . Urban, R. J. (2001). Mechanical load increases muscle igf-i and androgen receptor mrna concentrations in humans. American Journal of Physiology Endocrinology and Metabolism, 280(3), E383-390.

Berk, K. A., Buijks, H., Ozcan, B., Van't Spijker, A., Busschbach, J. J., \& Sijbrands, E. J. (2012). The prevention of weight regain in diabetes type 2 (power) study: The effectiveness of adding a combined psychological intervention to a very low calorie diet, design and pilot data of a randomized controlled trial. BioMed Central Public Health, 12, 1026. doi:10.1186/1471-2458$12-1026$

Bollheimer, L. C., Buettner, R., Pongratz, G., Brunner-Ploss, R., Hechtl, C., Banas, M., . . Fellner, C. (2012). Sarcopenia in the aging high-fat fed rat: A pilot study for modeling sarcopenic obesity in rodents. Biogerontology, 13(6), 609-620. doi:10.1007/s10522-012-9405-4

Bray, G. A., Smith, S. R., de Jonge, L., Xie, H., Rood, J., Martin, C. K., . . Redman, L. M. (2012). Effect of dietary protein content on weight gain, energy expenditure, and body composition during overeating: A randomized controlled trial. Journal of the American Medical Association, 307(1), 47-55. doi:10.1001/jama.2011.1918

Bryner, R. W., Ullrich, I. H., Sauers, J., Donley, D., Hornsby, G., Kolar, M., \& Yeater, R. (1999). Effects of resistance vs. Aerobic training combined with an 800 calorie liquid diet on lean body mass and resting metabolic rate. Journal of the American College of Nutrition, 18(2), 115-121.

Chaston, T. B., Dixon, J. B., \& O'Brien, P. E. (2007). Changes in fat-free mass during significant weight loss: A systematic review. International Journal of Obesity (Lond), 31(5), 743-750. doi:0803483 [pii] 10.1038/sj.ijo.0803483

Collaborators, G. O. (2017). Health effects of overweight and obesity in 195 countries over 25 years. New England Journal of Medicine. doi:10.1056/NEJMoa1614362 
Jo, E., Cain, A., Prado, C.M., Brown, A.F., Ormsbee, M.J., Smith, D., Snyder, K., Kim, J-S. / Californian Journal of Health

Promotion 2017, Volume 15, Issue 3, 25-36.

Donnelly, J. E., Blair, S. N., Jakicic, J. M., Manore, M. M., Rankin, J. W., Smith, B. K., \& Medicine, A. C. o. S. (2009). American college of sports medicine position stand. Appropriate physical activity intervention strategies for weight loss and prevention of weight regain for adults. Medicine and Science in Sports and Exercise, 41(2), 459-471. doi:10.1249/MSS.0b013e3181949333

Donnelly, J. E., Jakicic, J., \& Gunderson, S. (1991). Diet and body composition. Effect of very low calorie diets and exercise. Sports Medicine, 12(4), 237-249.

Donnelly, J. E., Pronk, N. P., Jacobsen, D. J., Pronk, S. J., \& Jakicic, J. M. (1991). Effects of a very-lowcalorie diet and physical-training regimens on body composition and resting metabolic rate in obese females. American Journal of Clinical Nutrition, 54(1), 56-61.

Donnelly, J. E., Sharp, T., Houmard, J., Carlson, M. G., Hill, J. O., Whatley, J. E., \& Israel, R. G. (1993). Muscle hypertrophy with large-scale weight loss and resistance training. American Journal of Clinical Nutrition, 58(4), 561-565.

Eston, R. G., Shephard, S., Kreitzman, S., Coxon, A., Brodie, D. A., Lamb, K. L., \& Baltzopoulos, V. (1992). Effect of very low calorie diet on body composition and exercise response in sedentary women. European Journal of Applied Physiology and Occupational Physiology, 65(5), 452-458.

Fine, J. T., Colditz, G. A., Coakley, E. H., Moseley, G., Manson, J. E., Willett, W. C., \& Kawachi, I. (1999). A prospective study of weight change and health-related quality of life in women. Journal of the American Medical Association, 282(22), 2136-2142. doi:joc90399 [pii]

Finer, N. (2001). Low-calorie diets and sustained weight loss. Obesity Research, 9 Suppl 4, 290S-294S. doi:10.1038/oby.2001.133

Finer, N., Swan, P. C., \& Mitchell, F. T. (1986). Metabolic rate after massive weight loss in human obesity. Clinical Science (Lond), 70(4), 395-398.

Finkelstein, E. A., Fiebelkorn, I. C., \& Wang, G. (2003). National medical spending attributable to overweight and obesity: How much, and who's paying? Health Affairs (Millwood), Suppl Web Exclusives, W3-219-226.

Flegal, K. M., Carroll, M. D., Kit, B. K., \& Ogden, C. L. (2012). Prevalence of obesity and trends in the distribution of body mass index among us adults, 1999-2010. Journal of the American Medical Association, 307(5), 491-497. doi:jama.2012.39 [pii] 10.1001/jama.2012.39

Goisser, S., Kemmler, W., Porzel, S., Volkert, D., Sieber, C. C., Bollheimer, L. C., \& Freiberger, E. (2015). Sarcopenic obesity and complex interventions with nutrition and exercise in communitydwelling older persons--a narrative review. Clinical Interventions in Aging, 10, 1267-1282. doi:10.2147/CIA.S82454

Hammer, R. L., Barrier, C. A., Roundy, E. S., Bradford, J. M., \& Fisher, A. G. (1989). Calorie-restricted low-fat diet and exercise in obese women. American Journal of Clinical Nutrition, 49(1), 77-85.

Hill, J. O., Sparling, P. B., Shields, T. W., \& Heller, P. A. (1987). Effects of exercise and food restriction on body composition and metabolic rate in obese women. American Journal of Clinical Nutrition, 46(4), 622-630.

Iannuzzi-Sucich, M., Prestwood, K. M., \& Kenny, A. M. (2002). Prevalence of sarcopenia and predictors of skeletal muscle mass in healthy, older men and women. The Journals of Gerontology. Series A, Biological Sciences and Medical Sciences, 57(12), M772-777.

Johannsen, D. L., Knuth, N. D., Huizenga, R., Rood, J. C., Ravussin, E., \& Hall, K. D. (2012). Metabolic slowing with massive weight loss despite preservation of fat-free mass. Journal of Clinical Endocrinology and Metabolism, 97(7), 2489-2496. doi:jc.2012-1444 [pii] 10.1210/jc.2012-1444

Krieger, J. W., Sitren, H. S., Daniels, M. J., \& Langkamp-Henken, B. (2006). Effects of variation in protein and carbohydrate intake on body mass and composition during energy restriction: A metaregression 1. American Journal of Clinical Nutrition, 83(2), 260-274. doi:83/2/260 [pii]

Longland, T. M., Oikawa, S. Y., Mitchell, C. J., Devries, M. C., \& Phillips, S. M. (2016). Higher compared with lower dietary protein during an energy deficit combined with intense exercise promotes greater lean mass gain and fat mass loss: A randomized trial. American Journal of Clinical Nutrition, 103(3), 738-746. doi:10.3945/ajcn.115.119339 
Jo, E., Cain, A., Prado, C.M., Brown, A.F., Ormsbee, M.J., Smith, D., Snyder, K., Kim, J-S. / Californian Journal of Health Promotion 2017, Volume 15, Issue 3, 25-36.

McIver, C. M., Wycherley, T. P., \& Clifton, P. M. (2012). Mtor signaling and ubiquitin-proteosome gene expression in the preservation of fat free mass following high protein, calorie restricted weight loss. Nutrition and Metabolism (Lond), 9(1), 83. doi:1743-7075-9-83 [pii] 10.1186/1743-7075-983

Miller, C. T., Fraser, S. F., Levinger, I., Straznicky, N. E., Dixon, J. B., Reynolds, J., \& Selig, S. E. (2013). The effects of exercise training in addition to energy restriction on functional capacities and body composition in obese adults during weight loss: A systematic review. Public Library of Science One, 8(11), e81692. doi:10.1371/journal.pone.0081692

Miller, S. L., \& Wolfe, R. R. (2008). The danger of weight loss in the elderly. The Journal of Nutrition Health and Aging, 12(7), 487-491.

Mustajoki, P., \& Pekkarinen, T. (2001). Very low energy diets in the treatment of obesity. Obesity Review, 2(1), 61-72.

Nelson, K. M., Weinsier, R. L., Long, C. L., \& Schutz, Y. (1992). Prediction of resting energy expenditure from fat-free mass and fat mass. American Journal of Clinical Nutrition, 56(5), 848856.

Ogden, C. L., Carroll, M. D., Fryar, C. D., \& Flegal, K. M. (2015). Prevalence of obesity among adults and youth: United states, 2011-2014. National Center for Health Statistics Data Brief(219), 1-8.

Pasiakos, S. M., Cao, J. J., Margolis, L. M., Sauter, E. R., Whigham, L. D., McClung, J. P., . . Young, A. J. (2013). Effects of high-protein diets on fat-free mass and muscle protein synthesis following weight loss: A randomized controlled trial. Federation of American Societies for Experimental Biology Journal, 27(9), 3837-3847. doi:10.1096/fj.13-230227

Pavlou, K. N., Steffee, W. P., Lerman, R. H., \& Burrows, B. A. (1985). Effects of dieting and exercise on lean body mass, oxygen uptake, and strength. Medicine and Science in Sports and Exercise, 17(4), 466-471.

Ravussin, E., Lillioja, S., Knowler, W. C., Christin, L., Freymond, D., Abbott, W. G., . . Bogardus, C. (1988). Reduced rate of energy expenditure as a risk factor for body-weight gain. New England Journal of Medicine, 318(8), 467-472. doi:10.1056/NEJM198802253180802

Roubenoff, R. (2004). Sarcopenic obesity: The confluence of two epidemics. Obesity Research, 12(6), 887-888. doi:10.1038/oby.2004.107

Saris, W. H. (2001). Very-low-calorie diets and sustained weight loss. Obesity Research, 9 Suppl 4, 295S301S. doi:10.1038/oby.2001.134

Schrager, M. A., Metter, E. J., Simonsick, E., Ble, A., Bandinelli, S., Lauretani, F., \& Ferrucci, L. (2007). Sarcopenic obesity and inflammation in the inchianti study. Journal of Applied Physiology, 102(3), 919-925. doi:10.1152/japplphysiol.00627.2006

Stiegler, P., \& Cunliffe, A. (2006). The role of diet and exercise for the maintenance of fat-free mass and resting metabolic rate during weight loss. Sports Medicine, 36(3), 239-262.

Thornell, L. E. (2011). Sarcopenic obesity: Satellite cells in the aging muscle. Current Opinion in Clinical Nutrition and Metabolic Care, 14(1), 22-27. doi:10.1097/MCO.0b013e3283412260

Tsai, A. G., \& Wadden, T. A. (2005). Systematic review: An evaluation of major commercial weight loss programs in the united states. Annals of Internal Medicine, 142(1), 56-66. doi:142/1/56 [pii]

Tsai, A. G., \& Wadden, T. A. (2006). The evolution of very-low-calorie diets: An update and metaanalysis. Obesity (Silver Spring), 14(8), 1283-1293. doi:10.1038/oby.2006.146

Villareal, D. T., Chode, S., Parimi, N., Sinacore, D. R., Hilton, T., Armamento-Villareal, R., ... Shah, K. (2011). Weight loss, exercise, or both and physical function in obese older adults. New England Journal of Medicine, 364(13), 1218-1229. doi:10.1056/NEJMoa1008234

Vink, R. G., Roumans, N. J., Arkenbosch, L. A., Mariman, E. C., \& van Baak, M. A. (2016). The effect of rate of weight loss on long-term weight regain in adults with overweight and obesity. Obesity (Silver Spring), 24(2), 321-327. doi:10.1002/oby.21346

Wadden, T. A., Foster, G. D., Letizia, K. A., \& Stunkard, A. J. (1992). A multicenter evaluation of a proprietary weight reduction program for the treatment of marked obesity. Archives of Internal Medicine, 152(5), 961-966. 
Wadden, T. A., \& Frey, D. L. (1997). A multicenter evaluation of a proprietary weight loss program for the treatment of marked obesity: A five-year follow-up. International Journal of Eating Disorders, 22(2), 203-212. doi:10.1002/(SICI)1098-108X(199709)22:2<203::AIDEAT13>3.0.CO;2-1 [pii]

Walsh, M. F., \& Flynn, T. J. (1995). A 54-month evaluation of a popular very low calorie diet program. Journal of Family Practice, 41(3), 231-236.

Weinheimer, E. M., Sands, L. P., \& Campbell, W. W. (2010). A systematic review of the separate and combined effects of energy restriction and exercise on fat-free mass in middle-aged and older adults: Implications for sarcopenic obesity. Nutrition Review, 68(7), 375-388. doi:10.1111/j.17534887.2010.00298.x

Zamboni, M., Mazzali, G., Fantin, F., Rossi, A., \& Di Francesco, V. (2008). Sarcopenic obesity: A new category of obesity in the elderly. Nutrition, Metabolism, and Cardiovascular Diseases, 18(5), 388-395. doi:10.1016/j.numecd.2007.10.002

\author{
Author Information \\ *Jeong-Su Kim, Ph.D., FACSM \\ Associate Professor, Graduate Program Director \\ Department of Nutrition, Food and Exercise Sciences \\ College of Human Sciences \\ Florida State University \\ 432 Sandels Building \\ Tallahassee, FL 32306-1493 \\ Office: (850) 644-4795 \\ Fax: (850) 645-5000 \\ jkim6@fsu.edu \\ * corresponding author
}

